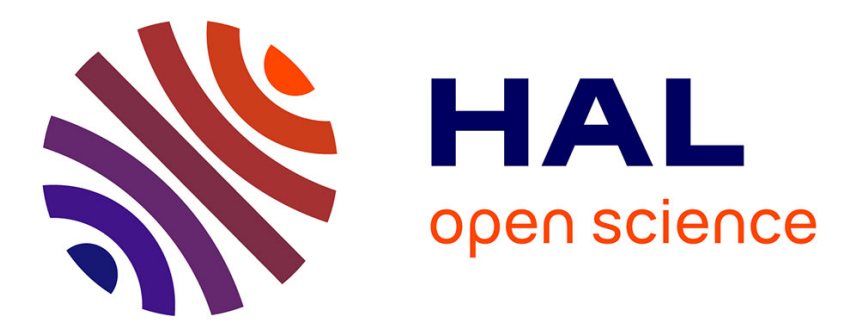

\title{
Application of Thermodynamic Calculations to Study High Temperature Behavior of TaC-Strengthened Co-base Superalloys
}

\author{
S. Michon, P. Berthod, L. Aranda, C Rapin, R Podor, P Steinmetz
}

\section{- To cite this version:}

S. Michon, P. Berthod, L. Aranda, C Rapin, R Podor, et al.. Application of Thermodynamic Calculations to Study High Temperature Behavior of TaC-Strengthened Co-base Superalloys. Calphad, 2003, 10.1016/j.calphad.2003.12.003 . hal-02398210

\author{
HAL Id: hal-02398210 \\ https://hal.science/hal-02398210
}

Submitted on 7 Dec 2019

HAL is a multi-disciplinary open access archive for the deposit and dissemination of scientific research documents, whether they are published or not. The documents may come from teaching and research institutions in France or abroad, or from public or private research centers.
L'archive ouverte pluridisciplinaire HAL, est destinée au dépôt et à la diffusion de documents scientifiques de niveau recherche, publiés ou non, émanant des établissements d'enseignement et de recherche français ou étrangers, des laboratoires publics ou privés. 


\title{
Application of Thermodynamic Calculations to Study High Temperature Behavior of TaC-Strengthened Co-base Superalloys
}

\author{
S. Michon, P. Berthod*, L. Aranda, C. Rapin, R. Podor, P. Steinmetz \\ Laboratoire de Chimie du Solide Minéral (UMR 7555), Université Henri Poincaré \\ BP 239, 54506 Vandoeuvre-lès-Nancy - France \\ *Corresponding author's e-mail : patrice.berthod@centraliens-lille.org \\ Post-print version of the article Calphad, Vol. 27, pp. 289-294 (2003); doi:10.1016/j.calphad.2003.12.003
}

\begin{abstract}
A database for cobalt-base superalloys was built by combing the binary and ternary thermodynamic descriptions available in the SSOL (SGTE) database and from the literature. Using this database, results of thermodynamic calculations for several cobalt-base superalloys were compared to the experimentally observed microstructure of the alloys after homogenization at high temperatures and quenching. Three examples are presented: prediction of phase equilibria versus temperature and composition; selection of highly refractory materials using isothermal sections; and evaluation of local melting temperature in the case of skin formation of Co-base alloy during air oxidation at $1300^{\circ} \mathrm{C}$. The agreement between calculated prediction and experimental observation is satisfactory.
\end{abstract}

\section{Introduction}

Cobalt-base superalloys are currently used as bulk materials for parts of aeronautic turbines, which can endure mechanical and thermal stresses at high temperature. The short lifetime of these parts incited us to search for more resistant alloys with higher solidus temperature and mechanical resistance. Thermodynamic calculations can be a very useful tool for selecting better chemical compositions and microstructures for the alloys. However, a good thermodynamic description of the alloy system is needed for these calculations.

The studied cobalt-base alloys are strengthened by tantalum carbide. These alloys contain the following elements: $\mathrm{Co}, \mathrm{Ni}, \mathrm{Cr}$, Ta and $\mathrm{C}$. A database containing these elements was built by combing the binary and ternary thermodynamic descriptions available in the SSOL (SGTE) database and from the literature. To validate the database, calculated values using the database were compared with experimental values obtained in the present work.

Some examples of calculations for cobalt-base systems are presented. The first group of examples concerns the prediction of phases versus temperature and composition. The other group concerns the calculation of isothermal sections that are useful for the identification of the most highly refractory alloys.

\section{Experimental Method}

\section{Alloy Choice and Preparation}

The composition and designation of the six cobalt-base superalloys used for this work are listed in Table 1. These chosen compositions are representative of the cobalt-base superalloys that are commonly used for industrial or aeronautic hot parts. The alloy compositions were chosen so that their microstructures would be simple enough to form a limited number of phases and to stay in the composition range defined in the database.

Each element present in the superalloy has a specific role: 
1. Nickel stabilizes the face centered cubic structure of the matrix of cobalt-base superalloys.

2. Chromium ensures the resistance against high temperature oxidation and molten salts corrosion; it also participates to the formation of carbides that strengthen the superalloys.

3. Carbon is needed for the formation of carbides that are responsible for good mechanical properties at high temperature, creep resistance in particular.

4. Tantalum strengthens the alloys by forming a solid solution and is also involved in the formation of carbides.

\begin{tabular}{llcccc} 
Table 1 & \multicolumn{5}{c}{ Compositions of the Studied Cobalt-Base Superalloys } \\
\cline { 2 - 6 } & Co & $\begin{array}{c}\mathrm{Ni} \\
\text { (wt.\%) }\end{array}$ & $\begin{array}{c}\mathrm{Cr} \\
\text { (wt.\%) }\end{array}$ & $\begin{array}{c}\mathrm{C} \\
\text { (wt.\%) }\end{array}$ & $\begin{array}{c}\mathrm{Ta} \\
\text { (wt.\%) }\end{array}$ \\
\hline Alloy 1 & bal. & 8.7 & 28.4 & 0.37 & 5.8 \\
Alloy 2 & bal. & 8.7 & 28.4 & 0.80 & 5.8 \\
Alloy 3 & bal. & 8.7 & 28.4 & 0.19 & 3 \\
Alloy 4 & bal. & 8.7 & 28.4 & 0.25 & 4 \\
Alloy 5 & bal. & 8.7 & 28.4 & 0.33 & 5 \\
Alloy 6 & bal. & 8.7 & 28.4 & 0.44 & 7 \\
\hline
\end{tabular}

The six superalloys were prepared from the pure elements (>99.9\%) using an induction furnace under Argon gas. Samples were of compact shape and weighed about $100 \mathrm{~g}$. The alloys were heat treated at $1200{ }^{\circ} \mathrm{C}$ for 100 hours. The samples were finally quenched in air.

\section{Sample Preparation and Surface Analysis}

The samples were cut in two parts using an Accutom-2 saw equipped with a diamond blade, then embedded in a cold resin (Araldite CY230 +Strengthener Escil HY956). The cross sections were obtained by polishing with SiC papers (80 to 1200 grid under water) and with diamond pastes ( $6 \mu \mathrm{m}$ and $3 \mu \mathrm{m})$. Scanning Electron Microscopy (SEM), used in Back Scattered Electron mode (BSE) under an acceleration voltage equal to $20 \mathrm{kV}$, allowed to clearly observe the phases of the alloys. Electron Probe Microanalysis in spot mode was used to determine the alloy compositions.

\section{Thermal Analysis}

Differential Scanning Calorimetry was carried out for several alloys to determine the melting temperatures. The heating rate was $20{ }^{\circ} \mathrm{C} / \mathrm{min}$ up to $1200{ }^{\circ} \mathrm{C}$ then $5{ }^{\circ} \mathrm{C} / \mathrm{min}$ up to $1470{ }^{\circ} \mathrm{C}$. The cooling rate was $-5^{\circ} \mathrm{C} / \mathrm{min}$ down to $1200{ }^{\circ} \mathrm{C}$ then $-20^{\circ} \mathrm{C} / \mathrm{min}$ down to room temperature. The plots of enthalpy versus temperature allow the determination of the alloy melting temperature. For each alloy a difference of nearly $30^{\circ} \mathrm{C}$ is often observed between the two solidus temperatures, probably due to kinetic reasons. Thus the considered solidus temperatures are the average of the heating and cooling values, as usually made in such measurements.

\section{Air Exposures}

The sample Alloy 1 was exposed to air for 100 hours at $1300{ }^{\circ} \mathrm{C}$ to evaluate the metal surface modifications resulting from air oxidation.

\section{Database Constitution}

A thermodynamic description of the Co-Cr-Ni-Ta-C has to be established first. However, none of the databases available to us in the Thermo-Calc software [1] contains all the thermodynamic descriptions for the system involved. The most useful database is SSOL [2], which has descriptions for the following binary and ternary systems: C-Co, C-Ni, C-Cr, Co-Ni, Co-Cr, Cr-Ni, C-Co-Cr, C-Co-Ni, C-Cr-Ni and Co-Cr-Ni. The descriptions obtained from the literature [3-8] for the following systems are added: Ta-C, Ta-Ni, Ta-Cr, Ta-Co, Co-Ta-C, Ni-Cr-Ta. Table 2 and Table 3 give a summary of the database content. 
Table 2 Thermodynamic descriptions of Binary Systems in the database

\begin{tabular}{|c|c|c|c|c|}
\hline Co-C & Ni-C & Cr-C & Ta-C & Co-Ni \\
\hline SSOL (SGTE) & SSOL (SGTE) & SSOL (SGTE) & $(3)$ & SSOL (SGTE) \\
\hline Co-Ta & Ni-Ta & Cr-Ta & Co-Cr & Ni-Cr \\
\hline$(4)$ & $(5)$ & $(6)$ & SSOL (SGTE) & SSOL (SGTE) \\
\hline
\end{tabular}

Table 3 Thermodynamic descriptions of Ternary Systems in the database

\begin{tabular}{|c|c|c|c|c|}
\hline Co-Ni-Cr & Co-Cr-Ta & Co-Ta-C & Co-Ni-Ta & Co-Cr-C \\
\hline SSOL (SGTE) & not added & $(7)$ & not added & SSOL (SGTE) \\
\hline Co-Ni-C & Ni-Cr-C & Ni-Cr-Ta & Ni-Ta-C & Cr-Ta-C \\
\hline SSOL (SGTE) & SSOL (SGTE) & $(8)$ & not added & not added \\
\hline
\end{tabular}

\section{Predictions and Comparison with Experiments}

\section{Determination of Phase Equilibria}

The new database thus obtained was used to evaluate the influence of the carbon concentration on the phases as a function of temperature. The equilibrium diagram for $\mathrm{Co}-28.4 \mathrm{Cr}-8.7 \mathrm{Ni}-5.8 \mathrm{Ta}-\mathrm{xC}$ calculated with Thermo-Calc for $\mathrm{x}$ varying between 0 and $1 \mathrm{wt} . \% \mathrm{C}$ is shown in Figure 1.

The diagram shows that a small variation of the $\mathrm{C}$ content strongly influences the structure of the alloys. For example, only the $\mathrm{TaC}$ carbide is present if the $\mathrm{C}$ content varies between 0.2 and 0.4 wt.\% (Alloy 1). For lower $\mathrm{C}$ contents $(<0.2 \mathrm{wt} . \%)$, Thermo-Calc predicts the occurrence of the Laves phase, $\mathrm{Co}_{2} \mathrm{Ta}(\mathrm{C} 36)$. If the $\mathrm{C}$ content is higher than $0.4 \mathrm{wt} . \%$, the chromium carbides should be present: at high temperature the $\mathrm{M}_{7} \mathrm{C}_{3}$ is the only stable carbide, whereas at lower temperature it is the $\mathrm{M}_{23} \mathrm{C}_{6}$.

Figure 1 shows how the microstructure should change with temperature for Alloy1:

1. below $870{ }^{\circ} \mathrm{C}$, the alloy is composed of a Co-base matrix with hcp structure and tantalum carbide $\mathrm{TaC}$,

2. between $870{ }^{\circ} \mathrm{C}$ and $950{ }^{\circ} \mathrm{C}$, the TaC carbides is still present. The Co matrix consists simultaneously of phases with the hcp and fcc structure,

3. in the $950{ }^{\circ} \mathrm{C}-1285{ }^{\circ} \mathrm{C}$ temperature range, the $\mathrm{TaC}$ carbide is present and only the fcc structure of Co matrix is stable,

4. at $1285^{\circ} \mathrm{C}$, the $\mathrm{TaC}$ carbide disappears and the alloy begin to melt,

5. at temperatures higher than $1373{ }^{\circ} \mathrm{C}$ the alloy is entirely molten.

On the other hand, the Alloy 2 should result in the formation of both chromium and tantalum carbides at temperatures below $1270^{\circ} \mathrm{C}$.

Microstructure observations of Alloy $1(0.37 \%$ C) and Alloy $2(0.8 \%$ C), Figure 2, using SEM in BSE mode, are in good agreement with the calculated predictions. Alloy1 only contains $\mathrm{TaC}$ carbide (the white phase) whereas Alloy 2 contains both $\mathrm{TaC}$ and $\mathrm{M}_{23} \mathrm{C}_{6}$ carbide $\left(\mathrm{M}_{23} \mathrm{C}_{6}\right.$ is the darkest phase).

\section{Determination of the Optimal Concentrations}

The availability of equilibrium diagrams allows us to determine the optimal concentration of a given element in order to reach the targeted properties, for example, good mechanical resistance at high temperatures. We know that the best mechanical properties of cobalt-base alloys reinforced by tantalum carbides are linked to both a high solidus temperature and the absence of chromium carbides. The latter are effectively unstable at high 


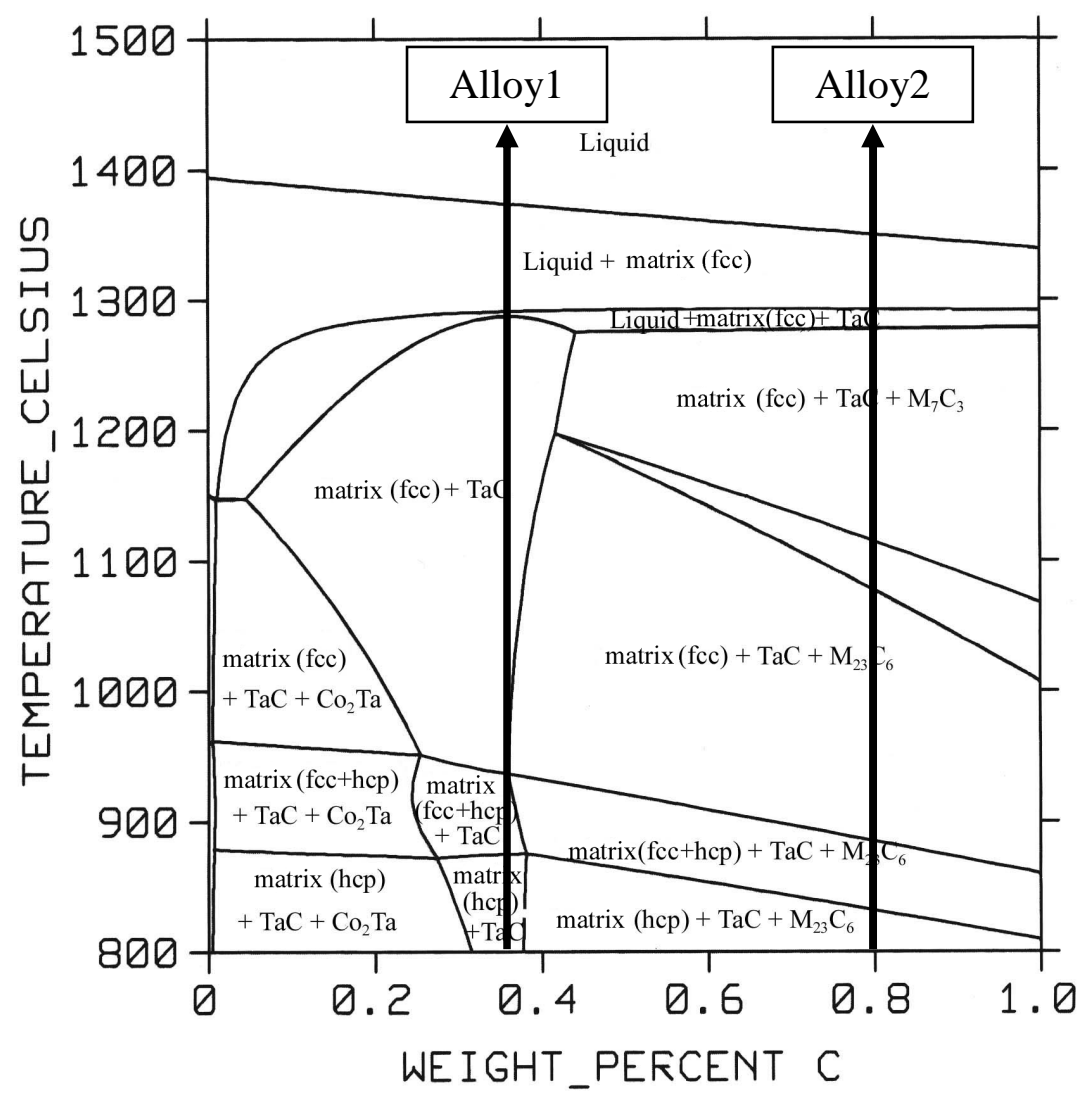

Figure 1 Calculated phase diagram for Co-28.4Cr-8.7Ni-5.8Ta-xC, with $\mathrm{x}$ between 0 and 1 wt.\%
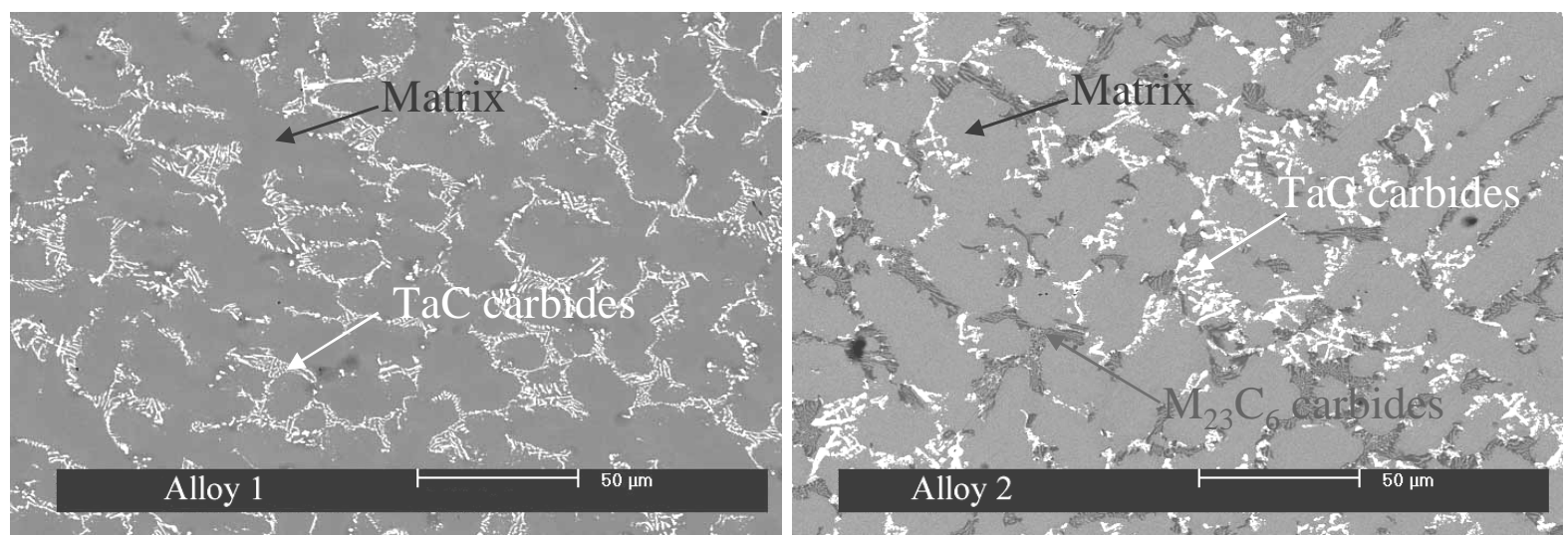

Figure $2 \quad$ BSE images of Alloy $1(0.37 \% \mathrm{C})$ and Alloy $2(0.80 \% \mathrm{C})$ microstructures

temperature and may decrease the mechanical resistance. According to Figure 1, Alloy $1(0.37$ wt.\% C) fulfills best the requirements: the Co matrix only contains tantalum carbide and the melting temperature is maximized $\left(1287^{\circ} \mathrm{C}\right)$.

\section{Determination of Phase Weight Fractions}

The fraction of each phase versus the temperature can be obtained from Thermo-Calc calculations. This is of great interest for the studied alloys, since their mechanical properties depend on the amount of $\mathrm{TaC}$ carbides, which solidifies in the grain boundaries and ensures good cohesion between grains.

Figure 3 and Figure 4 give the weight fraction for the different carbide types for Alloy 1 and Alloy 2 as a function of temperature in the $800-1300{ }^{\circ} \mathrm{C}$ range. 
Alloy 1

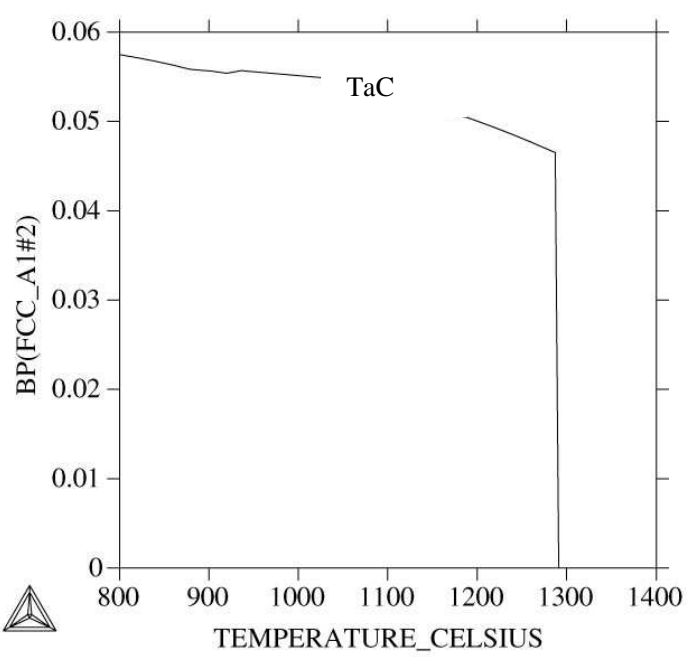

Alloy 2

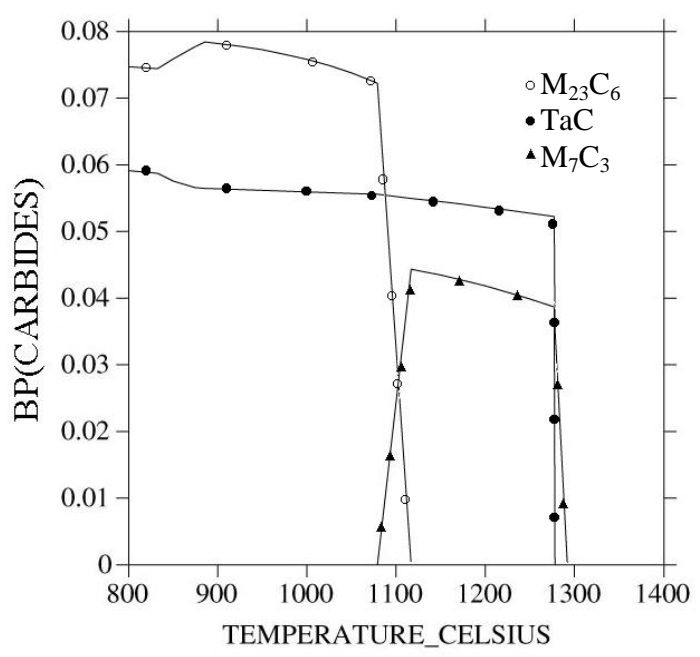

Figure 3 and Figure 4 Equilibrium weight fractions of the carbides in Alloy 1 and Alloy 2 as function of the temperature (BP: weight fraction of each phase in the alloy)

The $\mathrm{TaC}$ fraction present in Alloy 1 decreases from $5.8 \%$ to $4.8 \%$ when temperature increases from 800 ${ }^{\circ} \mathrm{C}$ to $1285{ }^{\circ} \mathrm{C}$. At this temperature, the alloy begins to melt and the TaC carbide disappears simultaneously. Several types of carbides are present in Alloy 2. In the temperature range of interest, the weight fraction of TaC carbide does not change and is equal to approximately $5.8 \%$. The $\mathrm{M}_{23} \mathrm{C}_{6}$ fraction is equal to $7.5 \%$ below 1100 ${ }^{\circ} \mathrm{C}$. This carbide is not stable above this temperature and is replaced by $4.2 \%$ of $\mathrm{M}_{7} \mathrm{C}_{3}$, which is stable up to $1285^{\circ} \mathrm{C}$.

\section{Determination of the Ta/C Ratio}

The effect of the simultaneous composition variation of two elements is also of interest. Indeed, the influence of $\mathrm{Ta}$ and $\mathrm{C}$ variations on the equilibrium phases should give a better understanding of our alloys' potential. Figure 5 and Figure 6 show isothermal sections for 0 to $10 \% \mathrm{Ta}$ and 0 to $1 \% \mathrm{C}$ at 1200,1250 and $1285^{\circ} \mathrm{C}$, respectively.

$\mathrm{C}$ and Ta compositions where the alloy is composed of only two solid phases (the Co matrix and TaC carbide) can be determined from Figure 5. The boundaries of this two-phase region are of interest because they allow the identification of compositions for alloys with the desired mechanical properties. The boundaries of the two-phase region are given by the following relations:

$$
\left\{\begin{array}{l}
\mathrm{W}(\mathrm{Ta})>15.79 \times \mathrm{W}(\mathrm{C})-0.895 \\
\mathrm{~W}(\mathrm{Ta})<13.33 \times \mathrm{W}(\mathrm{C})+4.06
\end{array}\right.
$$

$\mathrm{W}(\mathrm{X})$ corresponds to the weight percent of $\mathrm{X}$.

If the alloy lies outside the first boundary, it remains entirely solid at $1200{ }^{\circ} \mathrm{C}$, but contains undesired chromium carbides. If the alloy lies outside the second boundary, it will be partly liquid at $1200{ }^{\circ} \mathrm{C}$ and will not be suitable for applications at this temperature.

The isotherms calculated at $1250{ }^{\circ} \mathrm{C}$ and $1285{ }^{\circ} \mathrm{C}$ are shown in Figure 6. It can be seen that the composition range specified in Eq. 1 decreases with increasing temperature. At $1285^{\circ} \mathrm{C}$, this two-phase region becomes relatively narrow and is centered along the line: at. $\% \mathrm{C}=$ at. $\% \mathrm{Ta}$ (note the isotherm in Fig. 6 is plotted in weight percent). 


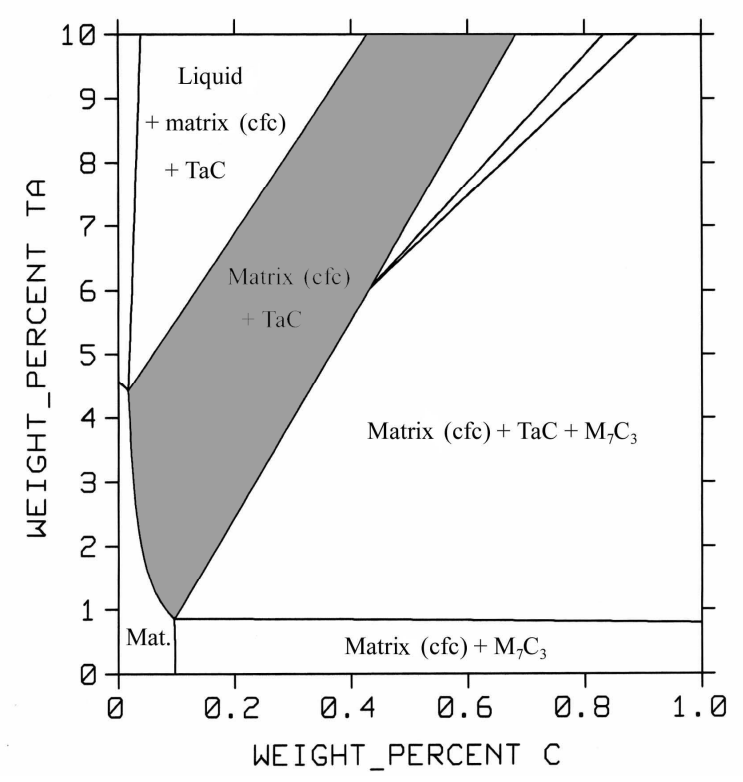

Figure 5 Equilibrium phase diagram for Co-28.4Cr-8.7Ni-xTa-yC at $1200{ }^{\circ} \mathrm{C}$

$1250^{\circ} \mathrm{C}$

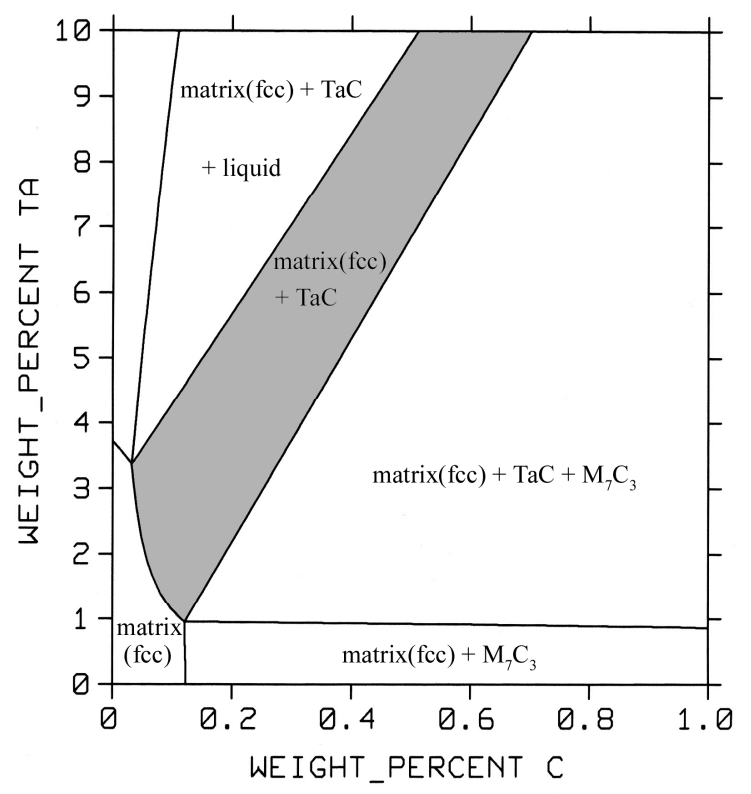

$1285^{\circ} \mathrm{C}$

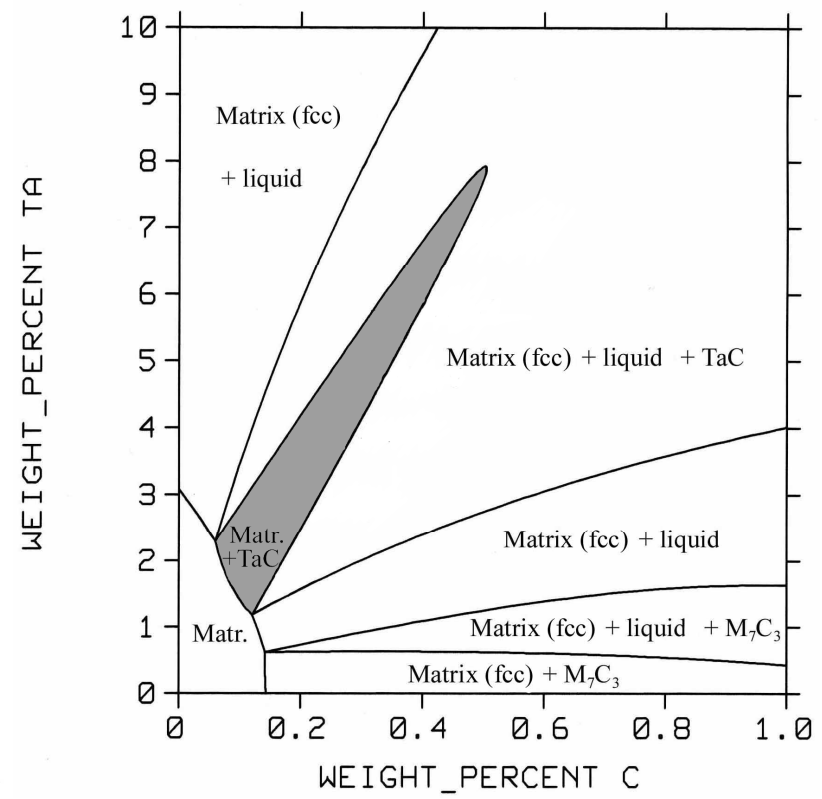

Figure 6 Equilibrium phase diagrams for Co-28.4Cr-8.7Ni-xTa-yC at $1250{ }^{\circ} \mathrm{C}$ and $1285^{\circ} \mathrm{C}$

Five alloys (Alloys 1, 3, 4, 5 and 6) with compositions in the 'matrix $+\mathrm{TaC}$ ' two-phase region at $1285{ }^{\circ} \mathrm{C}$ were prepared. The observed microstructures are in good agreement with thecalculation: the alloys are composed of a Co matrix and $\mathrm{TaC}$ carbide with different weight fractions according to the alloy composition.

\section{Melting Temperatures of the Alloys}

The solidus temperatures were determined by Differential Thermal Analyses and compared with those calculated using the database in Table 4. According to the calculation, the solidus temperatures of the alloys are practically identical: $1288 \pm 2{ }^{\circ} \mathrm{C}$. The temperatures derived from DTA are also within a small temperature range but are $50{ }^{\circ} \mathrm{C}$ higher than the calculated values. This difference could essentially be attributed to the lack of accuracy of the database built for the study. However, the results obtained from this database are sufficiently accurate to allow comparisons between the alloys and to select the more refractory alloy from our set of compositions. 
Table 4 Experimental (DTA) and Calculated Solidus Temperatures of Alloys 1, 3, 4, 5 and 6

\begin{tabular}{|c|c|c|c|}
\hline & $\begin{array}{c}\text { Solidus temperature }{ }^{\circ} \mathrm{C} \\
\text { Calculation }\end{array}$ & $\begin{array}{c}\text { Experimental (DTA) } \\
\text { melting temperature }{ }^{\circ} \mathrm{C}\end{array}$ & $\Delta \mathrm{T}^{\circ} \mathrm{C}$ \\
\hline Alloy 3 & 1290 & 1348 & 58 \\
\hline Alloy 4 & 1289 & 1336 & 47 \\
\hline Alloy 5 & 1288 & 1337 & 49 \\
\hline Alloy 1 & 1287 & 1338 & 51 \\
\hline Alloy 6 & 1286 & 1338 & 52 \\
\hline
\end{tabular}

\section{Evaluation of local Melting Temperature after Air Oxidation at $1300{ }^{\circ} \mathrm{C}$}

A local decrease of the solidus temperature due to a variation in the microstructure of the alloy, can lead to dramatic consequences in terms of mechanical resistance if the working temperature is close to the solidus temperature. This may be the case for Co-base superalloys that are exposed to high temperature where air oxidation or corrosion can cause large composition variation near the metal - oxide interface.

Alloy 1 was exposed to air oxidation at $1300^{\circ} \mathrm{C}$ for $100 \mathrm{~h}$ to determine its effect on the composition. The microstructure changed in a $200 \mu \mathrm{m}$ band below the metal-oxide interface. The TaC carbide disappeared and tantalum and chromium diffuse partly towards the surface where they are oxidized into $\mathrm{CrTaO}_{4}$ (white) and $\mathrm{Cr}_{2} \mathrm{O}_{3}$ (black) (Figure 7).

Table 5 summarizes the compositions determined by electron microprobe analyses for the first $400 \mu \mathrm{m}$ from the external surface. In the zone where carbides totally disappeared, the $\mathrm{C}$ content is considered negligible, as it has been shown elsewhere [9]. Calculations based on these microprobe results allow the determination of the melting temperature for each point. The results are plotted in Figure 8, where the melting temperature is

Table $5 \quad$ Microprobe Results from the Metal-Oxide Interface up to $400 \mu \mathrm{m}$ Depth

\begin{tabular}{|c|c|c|c|c|c|}
\hline $\mathrm{d}(\mu \mathrm{m})$ & $\mathrm{Co}$ & $\mathrm{Ni}$ & $\mathrm{Cr}$ & $\mathrm{Ta}$ & $\mathrm{C}$ \\
\hline 0 & bal & 11.40 & 12.97 & 0 & 0 \\
\hline 100 & bal & 11.20 & 17.33 & 0.69 & 0 \\
\hline 200 & bal & 10.07 & 19.89 & 1.05 & 0 \\
\hline 300 & bal & 9.65 & 23.77 & 5.80 & 0.37 \\
\hline 400 & bal & 9.42 & 26.59 & 5.80 & 0.37 \\
\hline
\end{tabular}

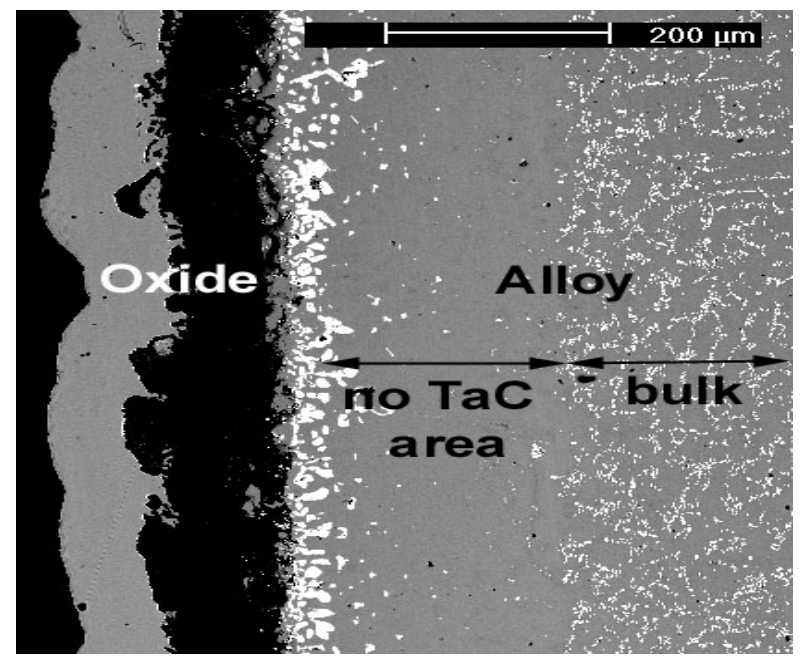

Figure $7 \quad$ Metal-oxide interface of Alloy1 after $100 \mathrm{~h}$ exposure to air at $1300{ }^{\circ} \mathrm{C}$ 
shown as function of the distance to the metal-oxide interface for the first $400 \mu \mathrm{m}$. The solidus temperature of the alloy surface does not decrease but rather increases with the local decrease of the chromium content. The calculations show that local melting near the surface cannot occur for this alloy after a long exposure to hot air.

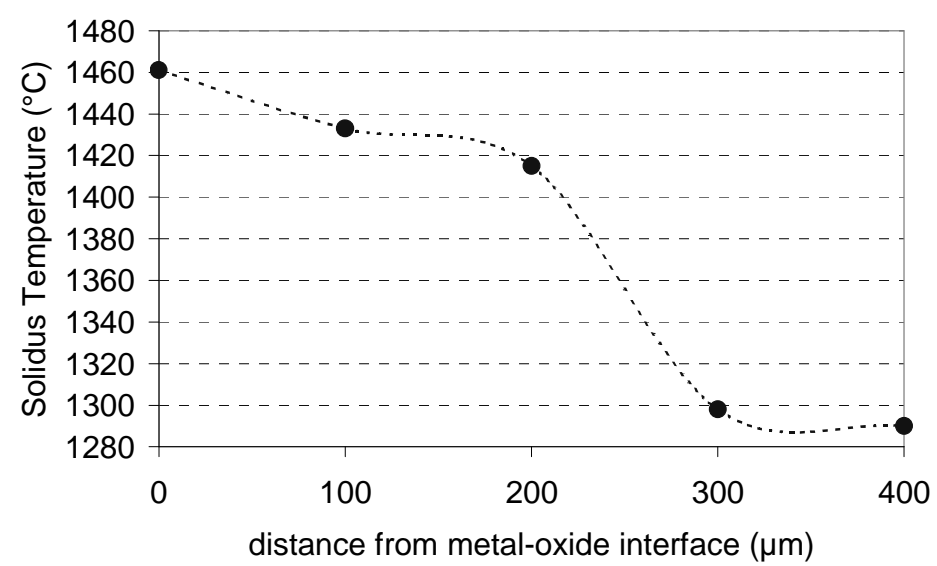

Figure $8 \quad$ Temperature profile for the first $400 \mu \mathrm{m}$ from the external surface for Alloyl after $100 \mathrm{~h}$ exposure to air at $1300^{\circ} \mathrm{C}$

\section{Conclusions}

Thermodynamic calculation of phase equilibria for the optimization of the alloy composition of a superalloy allowed:

-the prediction of the equilibrium phases

It is possible to predict the composition regimes in which the sought phases are formed. The calculations can also allow the prediction of the formation of undesirable phases ( $\sigma$ phase, TCP phases etc.). Based on the calculation, the microstructure, viz. the chemical composition of an alloy can be optimized to improve, for example, its mechanical properties.

-the selection of highest refractory materials

Even though it was not possible with the database employed for the present calculations to reproduce the experimental melting temperatures, the calculation allowed identifying the trend for the high temperature limits of the alloys that is in perfect agreement with the experimental results.

-the evaluation of the local melting temperature

The calculations were useful to determine the solidus temperature variations due to changes in the alloy composition at the surface after the alloy was exposed to an oxidizing atmosphere at high temperatures.

\section{References}

1. Thermo-Calc version N or Win NT: "Foundation for Computational Thermodynamics" Stockholm, Sweden, Copyright (1993, 2000).

2. $\quad$ SGTE: "Scientific Group Thermodata Europe" database, update 1992.

3. $\quad$ K. Frisk and A. Fernandez Guillermet, J. Alloys and Compounds, 238 (1996) 167-179.

4. $\quad$ Zi-Kui Liu and Y. Austin Chang, CALPHAD, 23 (1999) 339-356.

5. $\quad$ I. Ansara and M. Selleby, CALPHAD, 18 (1994) 99-107.

6. $\quad$ N. Dupin and I. Ansara, J. Phase Equilibria, 14 (1993) 451-456.

7. L. Dumitrescu, M. Ekroth and B. Jansson, Metall. Mater. Trans. A, 32A (2001) 2167-2174. 
8. $\quad$ N. Dupin and I. Ansara, Z. Metallkd., 87 (1996) 555-561.

9. P. Berthod, S. Michon, J. Di Martino, S. Mathieu, S. Noël, R. Podor and C. Rapin, submitted to CALPHAD. 